\title{
Management of Geotechnical Risks of Road Projects Using MADS-MOSAR Method
}

\author{
Kamila Amel Benachenhou ${ }^{\# 1}$, Thierry Verdel ${ }^{2}$, Mohammed Amine Allal ${ }^{\# 3}$, Anis Lakermi ${ }^{\# 4}$ \\ \# Departement de Genie-Civil, Faculté de la Technologie, Université Tlemcen, Algerie, Address : BP \\ 230 Chetouane, 13000, Tlemcen, Algerie \\ ${ }^{2}$ Georessources Lab, Université de Lorraine, CNRS, CREGU, Mines Nancy, Campus Artem, CS14234 \\ 54042 Nancy Cedex, France \\ ${ }^{1}$ benakamila@yahoo.fr \\ 2 thierry.verdel@mines- \\ nancy.univ-lorraine.fr \\ 3 aminallal@yahoo.fr \\ ${ }^{4}$ lak-anis@ hotmail.fr
}

\begin{abstract}
For the last few years, roads and motorways projects have been developing in Algeria, where the risk management remains timorous. Indeed, these projects exhibit many geotechnical disorders of natural or anthropic origin, which disturb their progress. Furthermore, the latent effects of these disorders can affect the life of the works as well as the safety and comfort of the users. Therefore, this paper addresses the use of the MADS-MOSAR method as a risk assessment method that can be used in the construction area to consider a wide range of risk sources including non-geotechnical ones. This method, which is widely used in industry, is tentatively used to identify the causes and consequences of undesired geotechnical events in the case of the main slip road " $A$ " at the exchange of the RN02 road in Tlemcen, Algeria. The choice of this method implies first a system modelling approach and a functional analysis to inventory all possible sources of danger and all possible interactions and to perform a global risk assessment. At the end, we show the relevance of this method in the field of geotechnical risk management for road projects.
\end{abstract}

Keywords- Risks, Geotechnical, Road project, MADS-MOSAR.

\section{Introduction}

For the last few years, questions about risk and safety in buildings and public works have come regularly to the front of the news, following spectacular accidents that have raised concerns of citizens and authorities. At the same time, construction engineering has undergone some significant changes in terms of organization and management. The requirements for improving productivity and quality while meeting deadlines, costs and performance assigned often lead to unstructured exchanges between the actors of the projects at the cost of risk management, which is often a hidden dimension in projects [1]. In the field of construction, as in many other areas, the risks of the project can come from many sources such as the behaviour of the actors, their interactions, and the lack of control of internal flows [3]. In practice, the design, construction and operation phases of civil engineering works are the life phases of civil projects in which the actors, people or property at risk and involved dangers are all different [23]. The complex relationships among the many actors [5] and the organization of the project [10] significantly contribute to the success or failure of projects. Therefore, proper management of material, energy, information and documentation flows is essential [2]. These multiple aspects pose the problem of the implementation of interoperability tools between the actors and the overall risk management.

In Algeria, large infrastructure projects, some of which were pending for more than twenty years, have been revived with new deadlines. The delays and cost overruns that have been generated confirm that the construction industry requires project management tools that ensure better control of construction projects, especially tools for risk management in general and for geotechnical risks in particular [23]

Therefore, the engineer is facing the question of how to best manage these risks as soon as possible and throughout the project, including the question of defining the measures to be implemented to reduce these risks or make them acceptable. Many tools and methods, initially developed in the industrial sector, now exist for risk analysis $[22,7,9,14,20]$. However, the implementation of these methods in the construction sector cannot be achieved without an accurate identification of the interactions and shared practices among the various stakeholders of civil projects [12].

The conventional approach currently used in construction projects, even if dedicated to the reduction of hazards and/or vulnerability, usually ignores two things :

- the complexity of the ongoing technical, administrative and regulatory operations in a public construction project and

- the large number and diversity of stakeholders involved that hinder formal communication between the different actors.

Therefore, we aim to show how the MADS-MOSAR method can help in assessing geotechnical risks in a way that exhibits the issue of the interoperability of stakeholders. The MADS-MOSAR method allows a systemic and 
systematic modelling of hazards $[16,13]$. It has been widely used in the French industry, where it has become one the most used method for global risk analysis. In the present paper, we are applying it to the geotechnical risk analysis of main slip road "A", $4 \mathrm{~km}$ in length, which links the city of Tlemcen to the east-west highway. The slip road is composed of a carriageway of $2 \times 3.5 \mathrm{~m}$ and a verge of $2 \times 1.3 \mathrm{~m}$. A «Road system» is first defined and then broken down into different subsystems for the purpose of the analysis. The study is developed on two subsystems: «Roadway system» and «Stakeholder environment system». The phase of life considered in this paper is the realization phase.

In the following, the terms «danger », « undesired event» and « risk» have slightly different meanings : « danger» means a situation which may initiate an « undesired event». An « undesired envent» is an event which may cause losses while a «risk» is an undesired event under assesment regarding the probability of its consequencies.

\section{Introducing the approach}

The risk analysis of our road system requires identification, evaluation, control and management of the feared events. To carry out this work, we used the MOSAR method (Méthode Organisée et Systémique d'Analyse des Risques - Organized and Systemic Risk Analysis) from Perilhon (2003, 2007), [16,18]. This method involves systemic modelling and notably enables an analysis of the main risks. The MOSAR method can be implemented according to two views/modules (Fig. 1):

- A macroscopic view through the A module, which consists of the analysis of key risks and

- A microscopic view through the B module, which consists of a detailed and additional analysis of technical and operational malfunctions identified in module A.

\section{A module: macroscopic vision}

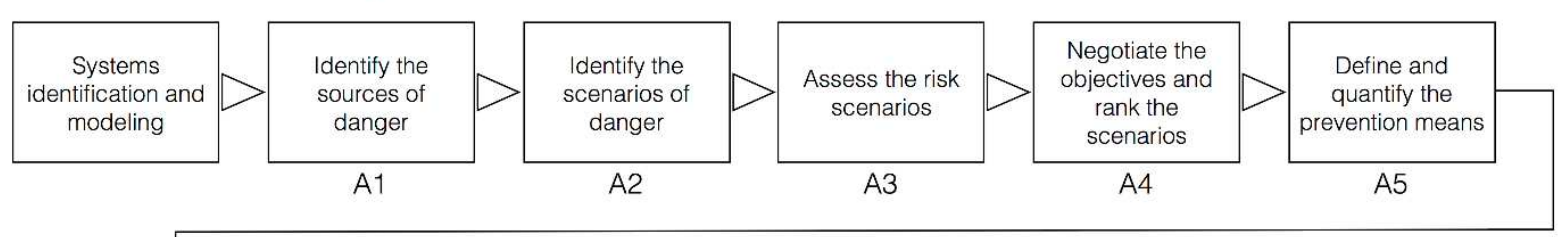

\section{B module: microscopic vision}

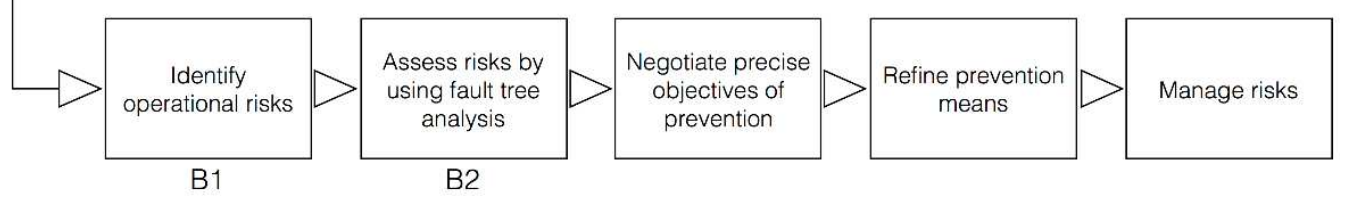

Fig. 1. The MOSAR methodology (adapted from Perilhon 2003)

In the present paper, we developed all steps of the A module that represent the structure of the MADS-MOSAR methodology. After dividing the system into subsystems, the first step (A1) consists of two further stages:

- The first consists of analysing each system in detail to track all dangers of which each subsystem can be the source. The identification of the sources of danger is accomplished using a general model called MADS (Methodologie d'Analyse des Dysfonctionnements dans les Systèmes - Methodology for the Dysfunctionning Analysis in Systems; [11, 18, 21, 19]) as shown in Fig 2. It is supported by a general table that lists all different sources of possible dangers (Perilhon 2003) in the manufacturing, storage, and transport of matter as well in energy and information systems. However, it does not necessarily fit the studied activity sector [6] and must be adjusted or completed if necessary, using the same structure but not the same content [18]. Based on the work of [4], we have created a specific table of dangers applicable to the construction sector and more particularly to road projects (Table 1). By doing this for all subsystems, we obtain large but possibly not exhaustive list of the dangers related to road projects.

- The second concerns the identification of the processes of danger by searching the initial events or triggers for each source of danger, the initiating events (internal and external) that may be the cause of these initial events and the principal events that can be generated by the initial events identified in accordance with the MADS model (Fig. 3). This allows Table A (Table $2 \mathrm{a} \& 2 \mathrm{~b}$ in this paper) to be completed with all identified processes of danger in the system under study [16]. Each subsystem in Tables 2 is characterized by inputs (initiating events) and outputs (principal events).

The second step (A2) regards the identification of scenarios of danger. Following the development of Table A, each subsystem is modelled as a black box exhibiting all internal or external initiating events as inputs and the principal events as outputs. Short scenarios of undesired events can then be structured from the links between them. We can later connect the outputs of some boxes that are of the same nature to some inputs of other boxes to 
identify long undesired scenarios of events [16]. For each released scenario, a set of consequence chains are developed showing the escalation of the events. These chains can conveniently be represented as event trees.

TABLE 1 System sources of danger in road construction projects

\begin{tabular}{|c|c|}
\hline $\begin{array}{l}\text { A- System sources of } \\
\text { economical danger }\end{array}$ & $\begin{array}{l}\text { A- } 1 \text { Sources of danger related to the market } \\
\text { Suppliers } \\
\text { Distributors } \\
\text { A- } 2 \text { Sourcer of danger related to financial resources } \\
\text { A- } 3 \text { Inflation } \\
\text { A- } 4 \text { Economic crisis }\end{array}$ \\
\hline $\begin{array}{l}\text { B- System sources of social } \\
\text { danger }\end{array}$ & $\begin{array}{l}\text { B- } 1 \text { Source of danger related to human behaviour } \\
\text { - Individuals } \\
\text { - } \quad \text { Group of individuals } \\
\text { - } \quad \text { Socio-professional conflicts } \\
\text { Corruption } \\
\end{array}$ \\
\hline $\begin{array}{l}\text { C- System sources of legal } \\
\text { danger }\end{array}$ & $\begin{array}{l}\text { C- } 1 \text { Sources of danger related to the legal context (the code of public sector contracts, city } \\
\text { building code, environmental code, labour code) } \\
\text { C- } 2 \text { Sources of danger related to the professional context } \\
\text { C- } 3 \text { Sources of danger related to the descriptive documents of the work (specifications, call } \\
\text { for tenders) } \\
\text { C- } 4 \text { Sources of danger related to the interpretation of the administrative specifications } \\
\text { C- } 5 \text { Sources of danger related to the choice of the type of contract } \\
\text { C- } 6 \text { Sources of danger related to the interpretation of the technical specifications } \\
\text { C- } 7 \text { Sources of danger related to the normative context and the statutory technical } \\
\text { documents }\end{array}$ \\
\hline $\begin{array}{l}\text { D- System sources of } \\
\text { technological danger }\end{array}$ & $\begin{array}{l}\text { D-1 Sources of danger related to road equipment (signposting, lighting, etc.) } \\
\text { D-2 Sources of danger related to equipment } \\
\text { D-3 Sources of danger related to materials } \\
\text { D-4 Sources of danger related to calculations } \\
\text { D-5 Sources of danger related of interpretations of the results } \\
\text { D-6 Sources of danger related to geotechnical investigations } \\
\text { D-7 Sources of danger related to the processes of construction }\end{array}$ \\
\hline $\begin{array}{l}\text { E- System sources of } \\
\text { environmental danger }\end{array}$ & $\begin{array}{l}\text { E-1 Sources of danger related to natural events: } \\
\text { - Geological (earthquakes, movements of soils, soil variability) } \\
\text { - Climatic (avalanches, storms, cyclones, tornadoes, hurricanes, gales, fog, drought, } \\
\text { E-2 Sources of danger related to surrounding infrastructure } \\
\text { - Dam } \\
\text { - Bridge } \\
\text { E-3 Sources of danger related to microorganisms (viruses, bacteria, epidemics, pandemics) } \\
\text { E-4 Sources of danger related to the conditions of work } \\
\text { E-5 Sources of danger related to workplaces }\end{array}$ \\
\hline $\begin{array}{l}\text { F- System sources of } \\
\text { organizational danger }\end{array}$ & $\begin{array}{l}\text { F-1 Sources of danger related to the communication process } \\
\text { F-2 Sources of danger related to monitoring and control procedures } \\
\text { F-3 Sources of danger related to document management (traceability) } \\
\text { F-4 Sources of danger related to the definition of the program } \\
\text { F-5 Sources of danger related to the planning process } \\
\text { F-6 Sources of danger related to decision-making processes (organization, progress, } \\
\text { validation of the decisions) } \\
\text { F-7 Sources of danger related to the hierarchy (definition of the responsibilities) } \\
\text { F-8 Sources of danger related to stakeholders } \\
\text { - Project owner } \\
\text { - Project supervisor/geotechnical engineering } \\
\text { - Contractor } \\
\text { - Subcontractor } \\
\text { - Geotechnical laboratory } \\
\text { - Control organism }\end{array}$ \\
\hline $\begin{array}{l}\text { G- System sources of } \\
\text { political danger }\end{array}$ & $\begin{array}{l}\text { G-1 Sources of danger related to the change of government } \\
\text { G-2 Sources of danger related to the change of the party in power } \\
\text { G-3 Sources of danger related to a coup }\end{array}$ \\
\hline
\end{tabular}

The third and fourth steps (A3 \& A4) concern the assessment and ranking of scenarios. This can be accomplished using either a quantitative or a qualitative assessment method. The negotiation of goals and ranking of risk scenarios is accomplished using a « Gravity vs. Probability » grid according to acceptability thresholds defined by a group of experts. 
The first module ends with the prevention means—i.e., technical and operational barriers—-that must be sought and qualified to prevent hazardous scenarios.

The second module (B module) allows a detailed analysis of a specific part of the system to be carried out using particular reliability tools to search for the technical (fault tree analysis, for instance) or operational dysfunctions.

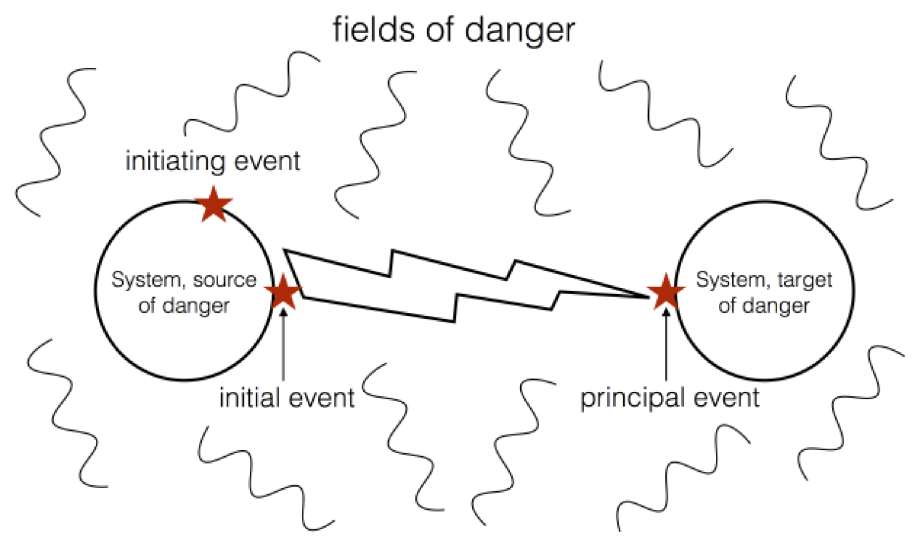

Fig. 2. The danger process model (adapted from Perilhon 2000)

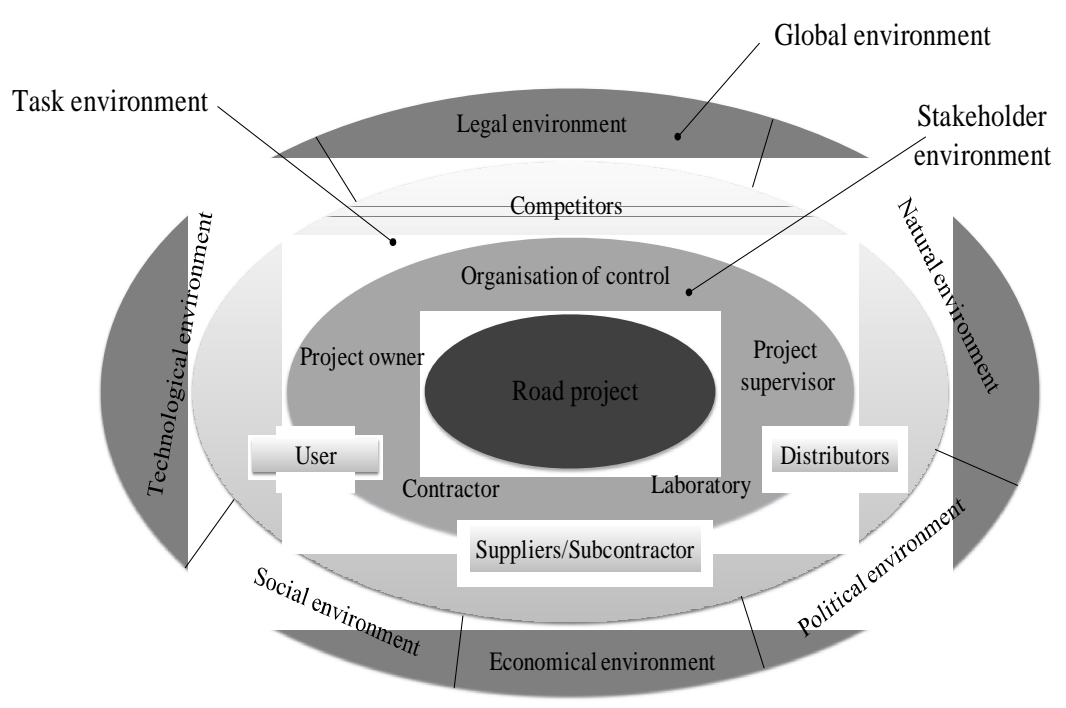

Fig. 3. Road project environment

\section{Modelling the system}

A road construction project involves a set of complex activities and requires particular attention regarding all interactions with its environment that are key factors and potential sources of danger. The breakdown of the road construction system into subsystems considered as sources of danger is based on Fig. 3, which represents potential sources of danger in interaction with construction projects. This leads to 7 sources of danger subsystems (Fig. 4) as follows:

- SS1-pavement;

- SS2-equipment of the road;

- SS3-machines;

- SS4-human resources;

- SS5-global environment;

- SS6-task environment and

- SS7-stakeholder environment. 


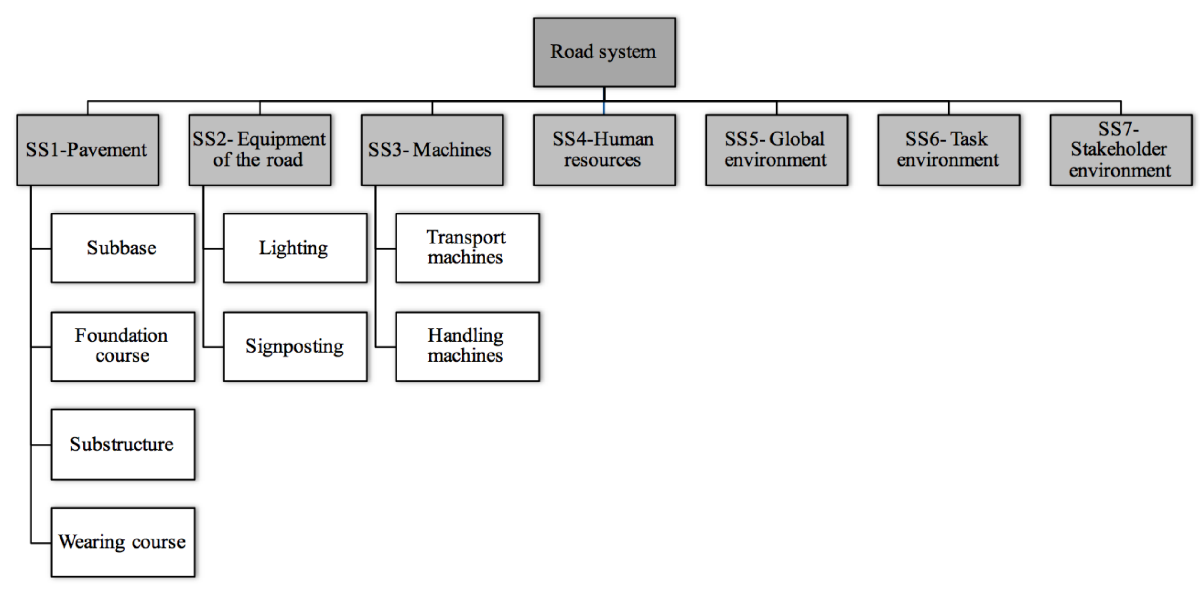

Fig. 4. Decomposition of the road system into subsystems

From the aforementioned table collecting the potential sources of danger in road construction projects (see Table 1), we can build Tables 2 (a) and (b) (named Table A in MOSAR methodology), which identifies the processes of danger for each subsystem and in which only the Roadway and Stakeholder environment subsystems within the realization phase are presented. After that, each subsystem in Tables 2 (a) and (b) is characterized by inputs (initiating events) and outputs (principal events). Short scenarios of undesired events can then be defined from the links between them. For better visibility and to avoid becoming lost in the maze of arrows, it is necessary to write the scenarios as they are built using different colours for each of them. Moreover, each scenario can be individually displayed (short scenario S2, for instance, in Fig. 5). It can be noticed in Fig. 5 and Fig. 6 that most of the principal events related to subsystems SS1 and SS7 are of a geotechnical or roadway degradation nature. These events can be started by natural, technical or anthropic initiating events. For example, in roadway subsystem SS1, we notice as initiating events some technical dysfunctions such as "Drainage system clogged" and "insufficient compaction"; some anthropic dysfunctions such as "Lack of competence" and "Lack of external/internal control"; and natural dysfunctions such as "Heavy rainfall" and "Earthquake".

We can then build 2 types of short scenarios connecting input events with output events. The first type, named "direct short scenario", concerns the cases in which a single input generates a single output. The second type concerns the scenarios in which several inputs must be combined to generate one or a combination of several outputs in Fig. 5. Short scenario S2 illustrates the second type in which a set of successive events of technical, anthropic or natural origin generates a degradation of the roadway, an interruption of activities and finally the principal event named "Economy contrast upset". From Tables II and the short scenarios, we can define long scenarios of events. These scenarios can be identified by connecting the outputs of a subsystem to the inputs of another. For instance, Fig. 7 highlights a long scenario (S1) involving subsystems SS1 and SS7. In long scenario $\mathrm{S} 1$, it is important to notice the sequence of events related to the interaction among the stakeholders including interoperability aspects: "Absence of internal communication system", "Absence of control and monitoring procedures", and "Lack of external/internal control". The latter induces technical errors such as "Non-conformed material used in a body of fill", "Inappropriate choice of the details of implementation", or "Insufficient compaction" and thus generates geotechnical problems and roadway degradation and results in upheaval in the deadlines and cost of the project. From the long and short scenarios and the assembling of them regarding the same event, we can build a logical tree that is a representation of the events chain able to generate an undesired event [8]. For instance, we can gather long scenario S1 and short scenario S2, both issued from the SS1 subsystem, within the logical tree represented in Fig. 8. 
TABLE 2 a Some processes of danger in subsystems SS1

\begin{tabular}{|c|c|c|c|c|c|c|}
\hline \multicolumn{2}{|c|}{$\begin{array}{l}\text { Establishment of the processes of } \\
\text { danger } \\
\text { Subsystem SS1: Roadway }\end{array}$} & \multirow[t]{2}{*}{ Life step } & \multirow[t]{2}{*}{ Initial events } & \multicolumn{2}{|c|}{ Initiating events } & \multirow[t]{2}{*}{ Principal events } \\
\hline $\begin{array}{c}\text { Type of } \\
\text { system } \\
\text { sources of } \\
\text { danger } \\
\text { (ref. Table 1) }\end{array}$ & $\begin{array}{c}\text { Target of system } \\
\text { sources of danger }\end{array}$ & & & Internal & External & \\
\hline E. 1 & $\begin{array}{l}\text { - Subbase course } \\
\text { - Foundation course } \\
\text { - Substructure } \\
\text { - Wearing course }\end{array}$ & Realization & $\begin{array}{l}\text { - Soil shear strength reduction } \\
\text { - Roadway flood } \\
\text { - Soil liquefaction } \\
\text { - Cavity collapse } \\
\text { - Modification of the properties of the clay soils } \\
\text { - Soil's bearing capacity reduction } \\
\text { - Insufficient bearing capacity } \\
\text { - Increase in the water content of the soil } \\
\text { - Decrease in the water content of the soil }\end{array}$ & $\begin{array}{l}\text { - Drainage system clogged } \\
\text { - Pipework rupture } \\
\text { - Base soil heterogeneity } \\
\text { unrecognized and/or } \\
\text { unconsidered }\end{array}$ & $\begin{array}{l}\text { - Earthquake } \\
\text { - Heavy rainfall } \\
\text { - Drought }\end{array}$ & $\begin{array}{l}\text { - Activity interruption } \\
\text { - Cracking of the roadway } \\
\text { - Subsidence } \\
\text { - Collapse } \\
\text { - Landslide } \\
\text { - Swelling } \\
\text { - Shrinkage }\end{array}$ \\
\hline D.6 & $\begin{array}{l}\text { - Subbase course } \\
\text { - Foundation course } \\
\text { - Substructure } \\
\text { - Wearing course }\end{array}$ & Realization & $\begin{array}{l}\text { - Cavity collapse } \\
\text { - Impossibility of execution of the earthwork } \\
\text { - Obstacle to good realization } \\
\text { - Complementary geotechnical investigations } \\
\text { - Errors in the laboratory and in situ } \\
\text { measurements }\end{array}$ & $\begin{array}{l}\text { - Soil heterogeneity not } \\
\text { considered } \\
\text { - Sensitive geological layers } \\
\text { not detected } \\
\text { - Bad follow- } \\
\text { up of the hydrous conditions } \\
\text { - Lack of competence }\end{array}$ & $\begin{array}{l}\text { - Insufficient geotechnical } \\
\text { investigations } \\
\text { - Ineffective recognition of soils } \\
\text { - Bad recognition of the } \\
\text { underground properties } \\
\text { - Incompetence of the geotechnical } \\
\text { laboratory } \\
\text { - Nonconformity of lab instrument }\end{array}$ & $\begin{array}{l}\text { - Subsidence } \\
\text { - Upset contract economy }\end{array}$ \\
\hline D.7 & $\begin{array}{l}\text { - Subbase course } \\
\text { - Foundation course } \\
\text { - Substructure } \\
\text { - Wearing course }\end{array}$ & Realization & $\begin{array}{l}\text { - Dysfunction of machines } \\
\text { - Unavailability of machines } \\
\text { - Nonconformity of work }\end{array}$ & $\begin{array}{l}\text { - Human error } \\
\text { - Lack of competence }\end{array}$ & $\begin{array}{l}\text { - Bad maintenance of the machines } \\
\text { - Insufficient compaction } \\
\text { - Disregard of the specified } \\
\text { requirements } \\
\text { - Unavailability of human } \\
\text { resources }\end{array}$ & $\begin{array}{l}\text { - Deformation of the roadway } \\
\text { - Cracking of the roadway }\end{array}$ \\
\hline D. 3 & $\begin{array}{l}\text { - Subbase course } \\
\text { - Foundation course } \\
\text { - Substructure } \\
\text { - Wearing course }\end{array}$ & Realization & $\begin{array}{l}\text { - Noncompliant materials } \\
\text { - Disruption of local materials }\end{array}$ & $\begin{array}{l}\text { - Lack of competence } \\
\text { - Lack of internal control } \\
\text { - No respect of the } \\
\text { standards } \\
\text { - Human error } \\
\text { - Bad resource planification }\end{array}$ & $\begin{array}{l}\text { - Lack of external control } \\
\text { - Excessive consumption of local } \\
\text { materials }\end{array}$ & $\begin{array}{l}\text { - Cracking of the roadway } \\
\text { - Activity interruption } \\
\text { - Excessively expensive } \\
\text { materials }\end{array}$ \\
\hline
\end{tabular}




\begin{tabular}{|c|c|c|c|c|c|c|}
\hline \multicolumn{2}{|c|}{$\begin{array}{c}\text { Establishment of the processes of } \\
\text { danger } \\
\text { Subsystem SS1: Roadway }\end{array}$} & \multirow[t]{2}{*}{ Life step } & \multirow[t]{2}{*}{ Initial events } & \multicolumn{2}{|c|}{ Initiating events } & \multirow[t]{2}{*}{ Principal events } \\
\hline $\begin{array}{c}\text { Type of } \\
\text { system } \\
\text { sources of } \\
\text { danger } \\
\text { (ref. Table 1) }\end{array}$ & $\begin{array}{c}\text { Target of system } \\
\text { sources of danger }\end{array}$ & & & Internal & External & \\
\hline C. $6-$ C. $7-$ C. 3 & - Roadway & Realization & $\begin{array}{l}\text { - Insufficiently compacted fill } \\
\text { - Nonconforming thickness } \\
\text { - Insufficient bearing capacity of the roadbed } \\
\text { - Nonconforming levelling of subbase course } \\
\text { - Insufficient soil bearing capacity }\end{array}$ & $\begin{array}{l}\text { - Lack of competence } \\
\text { - Defect of experience } \\
\text { - Misinterpretation of the } \\
\text { specifications } \\
\text { - Inappropriate choice of the } \\
\text { details of implementation } \\
\text { - Disregard of the specified } \\
\text { requirements }\end{array}$ & $\begin{array}{l}\text { - Bad definition of the } \\
\text { descriptive documents } \\
\text { of the work (specifications) }\end{array}$ & $\begin{array}{l}\text { - Fill landslide } \\
\text { - Deformation of the roadway } \\
\text { - Cracking of the roadway }\end{array}$ \\
\hline F. 8 & - Roadway & Realization & - Complementary geotechnical investigation & $\begin{array}{l}\text { - Simplistic modelling of } \\
\text { the geotechnical context } \\
\text { - Partial recognition } \\
\text { - Soil heterogeneity not } \\
\text { considered } \\
\text { - Human error } \\
\text { - Lack of competence }\end{array}$ & $\begin{array}{l}\text { - Programme of investigation } \\
\text { badly defined by the owner } \\
\text { - Badly defined geotechnical } \\
\text { missions }\end{array}$ & $\begin{array}{l}\text { - Delay in the project } \\
\text { - Deformation of the roadway } \\
\text { - Upset of contract economy }\end{array}$ \\
\hline F.2 & - Roadway & Realization & $\begin{array}{l}\text { - Low soil bearing capacity } \\
\text { - Insufficient bearing capacity of the roadbed } \\
\text { - Clogged drain } \\
\text { - Levelling border not respected } \\
\text { - Insufficiently compacted fill } \\
\text { - Nonconforming subbase course levelling }\end{array}$ & $\begin{array}{l}\text { - Human error } \\
\text { - Lack of competence } \\
\text { - Lack of maintenance }\end{array}$ & $\begin{array}{l}\text { - Control of bearing pressure not } \\
\text { carried out } \\
\text { - Control of levelling course not } \\
\text { carried out } \\
\text { - Nonconforming material used in } \\
\text { a body of fill } \\
\text { - Absence of control and } \\
\text { monitoring procedures } \\
\text { - Levelling border not defined in } \\
\text { the documents }\end{array}$ & $\begin{array}{l}\text { - Deformation of the roadway } \\
\text { - Cracking of the roadway } \\
\text { - Landslide }\end{array}$ \\
\hline F.6 & - Project & Realization & $\begin{array}{l}\text { - Slow decision making } \\
\text { - Birth of a rumour }\end{array}$ & $\begin{array}{l}\text { - Bad organization } \\
\text { - Bad decision making } \\
\text { - Absence of internal } \\
\text { communication system }\end{array}$ & $\begin{array}{l}\text { - Absence of external } \\
\text { communication system }\end{array}$ & - Delay in the project \\
\hline A. 1 & - Roadway & Realization & $\begin{array}{l}\text { - Delay of delivery } \\
\text { - Nonconformity } \\
\text { - New tender }\end{array}$ & $\begin{array}{l}\text { - Financial difficulties } \\
\text { - Human error } \\
\text { - Noncompliance }\end{array}$ & $\begin{array}{l}\text { - Cost increase } \\
\text { - Supply disruption }\end{array}$ & $\begin{array}{l}\text { - Delay in the project } \\
\text { - Over cost } \\
\text { - Deformation of the roadway } \\
\text { - Cracking of the roadway }\end{array}$ \\
\hline
\end{tabular}


Drainage system clogged

Pipework rupture

Base soil heterogeneity unrecognized And/or unconsidered

Soil heterogeneity not considered

Sensitive geological layers no detected

Bad follow up the hydrous conditions

Lack of competence

Human error

No respect of the standards

Earthquake

Heavy Rainfall

Drought

Insufficient geotechnical investigations

Ineffective recognition of soils

Bad recognition of underground propreties

Incompetence of the geotechnical laboratory

Bad maintenance of the machine

Insufficient compaction

Disregard of the specified requirements

Unavailability of human resources

Lack of external/internal control

Excessive consumption of local materials

Bad resource planification

No conformity of lab instrument

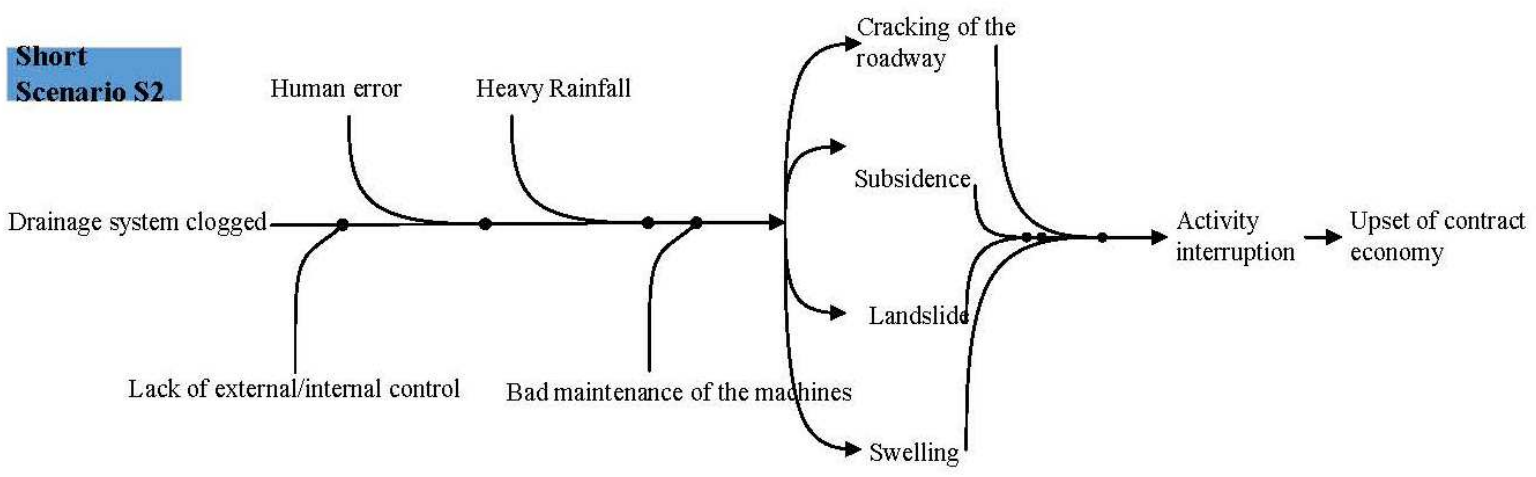

Fig. 5. Short scenarios of Roadway (SS1) 


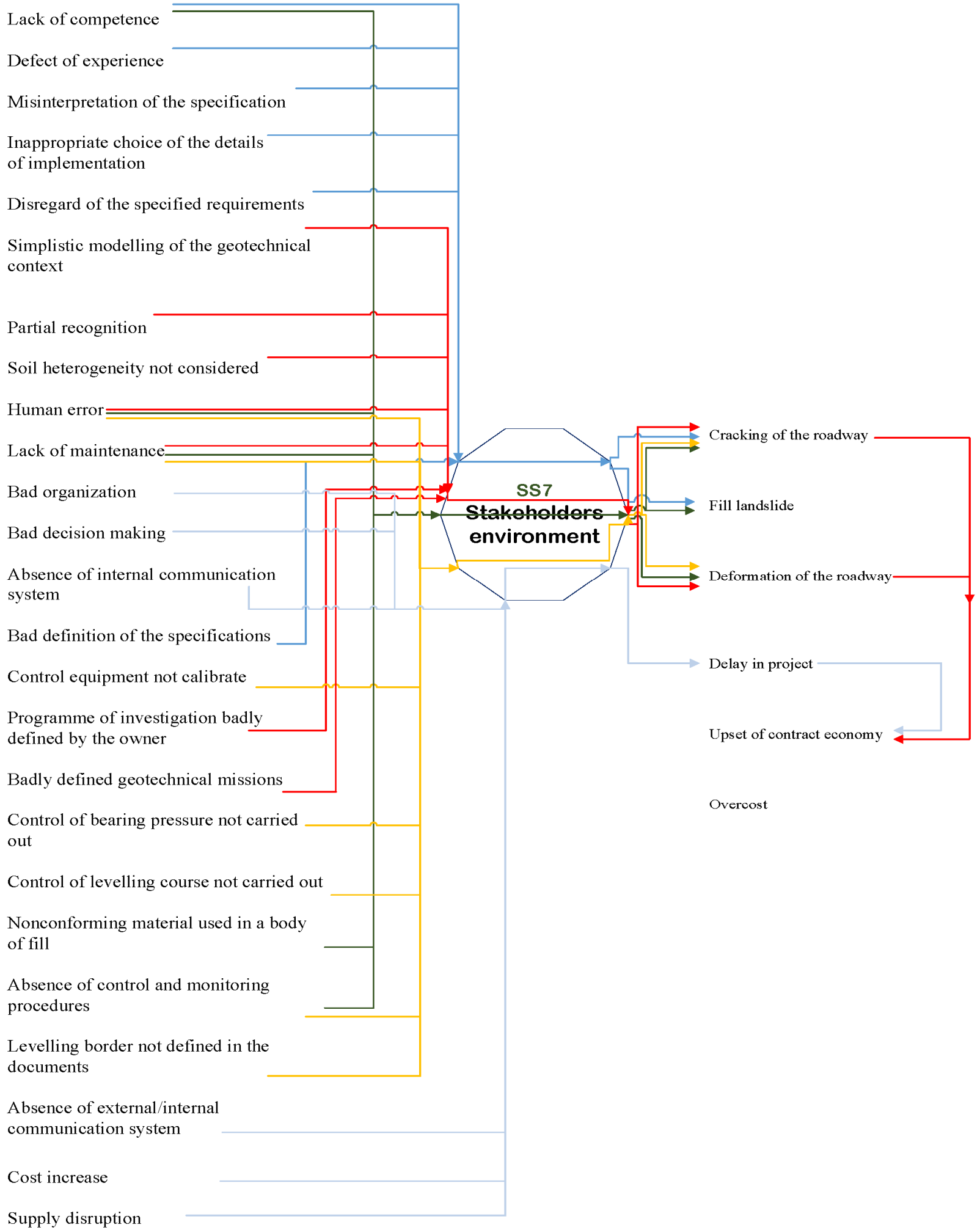

Fig. 6. Short scenarios of Stakeholders (SS7) 

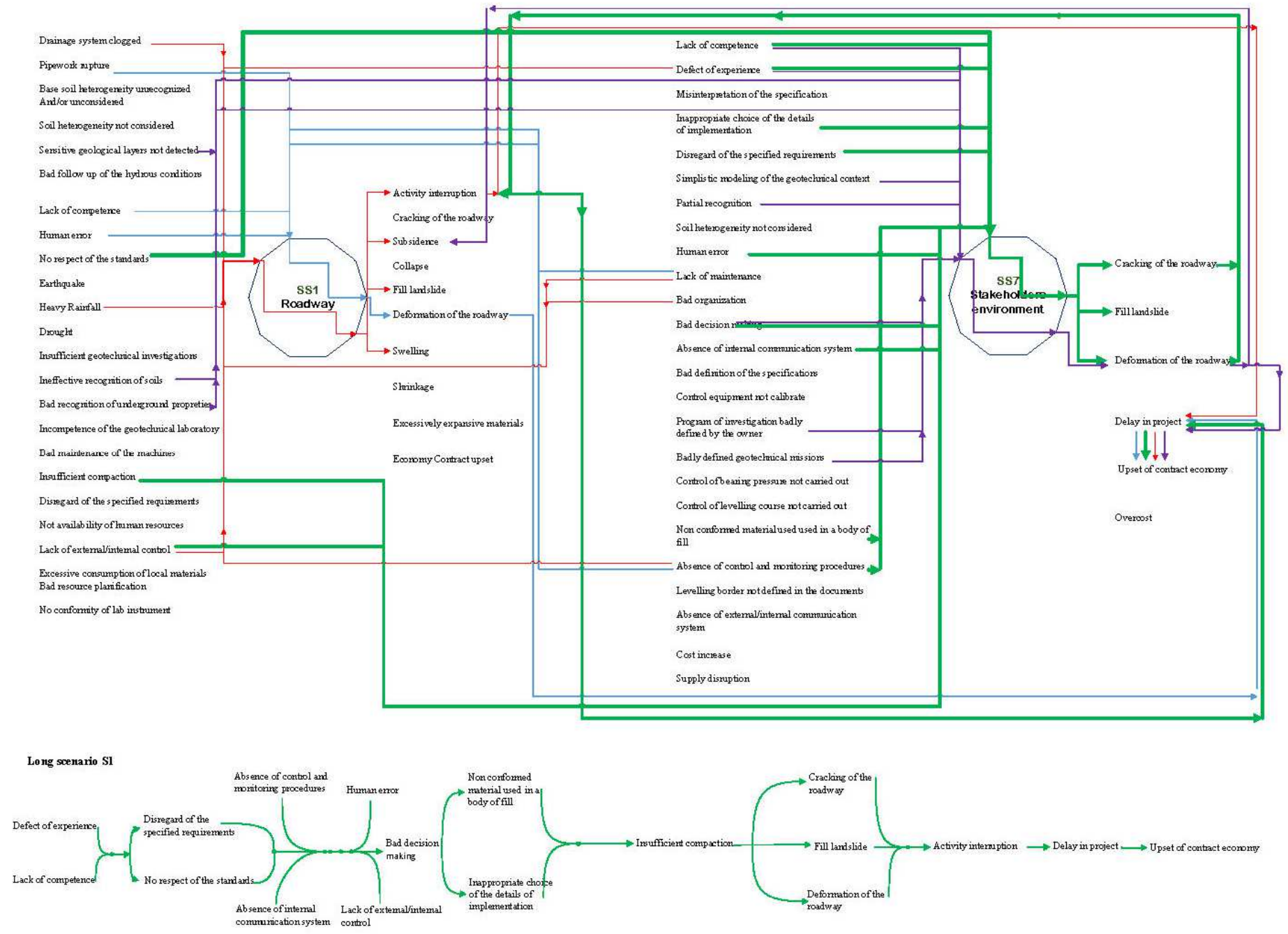

Fig. 7. Long scenario

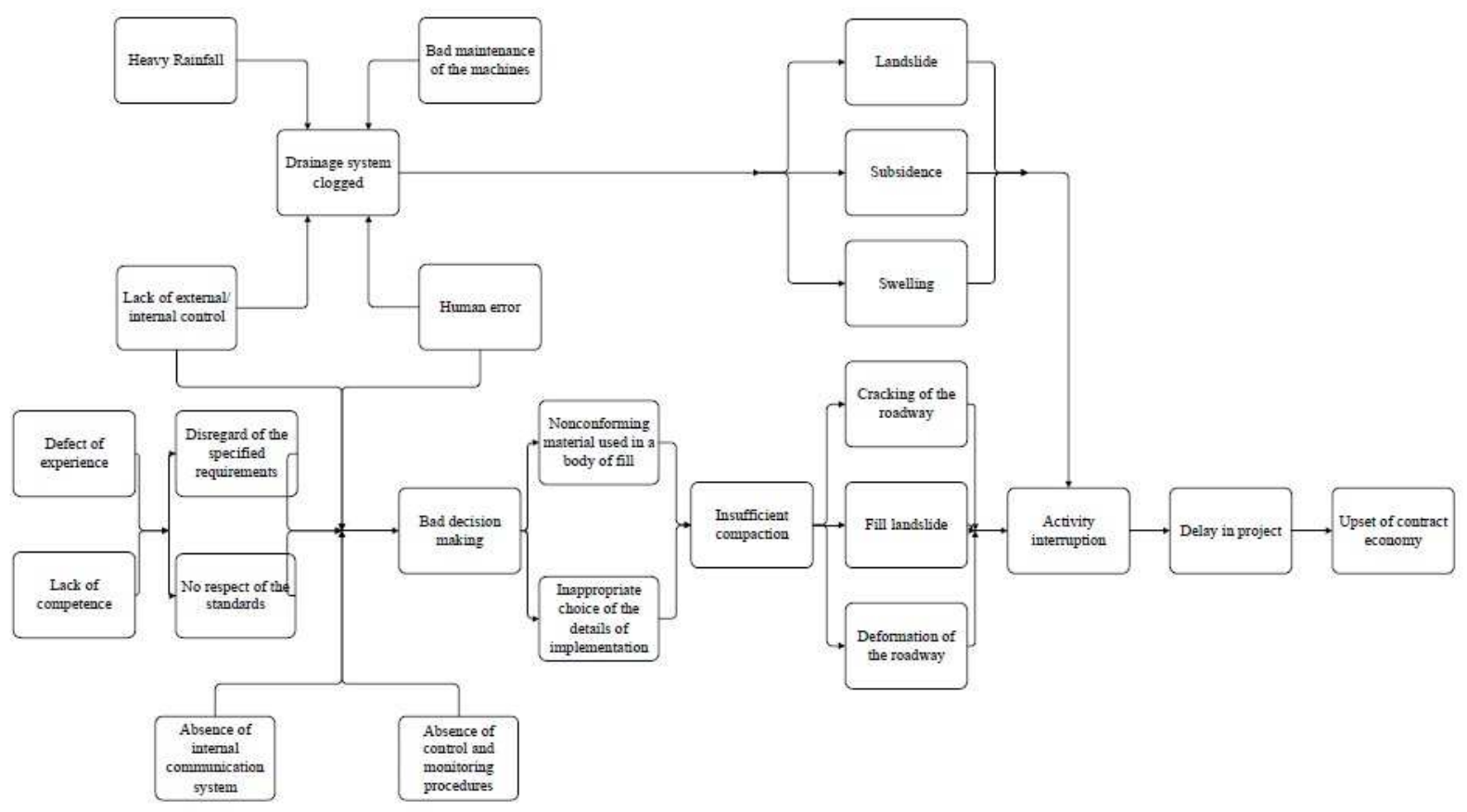

Fig. 8 Logical tree leading to the "upset of contract economy" 
The technique of black boxes helps in exhibiting many processes of danger. The number of scenarios presented in this paper is only a sample of all possible scenarios. Therefore, it is checked whether the identified sequences are possible after the evaluation of the scenarios in terms of gravity and probability. In the presented cases, long scenario S1 and short scenario S2 are found to be unacceptable, and technical barriers (TB) or usage barriers (UB) are proposed to reduce the level of risk as in Table 3. The logical tree shows that, in theory, it is sufficient to neutralize the primary events (those that appear first) so that the corresponding scenario may not take place [8]. To reinforce the prevention, we can also search for other possible barriers all along the scenario to the events or their sequences. For example, to reduce the risk of having a drainage system clogged (Fig. 8), we can ensure the maintenance of materials and set up a monitoring system or internal/external control. Once the barriers are defined, we must ensure that they do not generate any type of risk, and we must qualify them in time-i.e., ensure their durability. Thereafter, the extent to which the barriers inhibit the movement of the scenarios in a "Gravity vs. Probability" grid compared to the threshold of acceptability is determined. This stage closes the A module of MADS-MOSAR.

TABLE 3 Establishment of barriers for long Scenario S1 and short Scenario S2

\begin{tabular}{|c|c|c|c|}
\hline \multirow{2}{*}{ Barriers } & \multicolumn{2}{|l|}{ Scenarios } & \multirow{2}{*}{$\begin{array}{l}\text { Type } \\
\text { of } \\
\text { barriers }\end{array}$} \\
\hline & $\mathrm{S} 1$ & $\mathrm{~S} 2$ & \\
\hline Procedures & $\begin{array}{l}\text { - To set up a monitoring system and internal/external } \\
\text { control } \\
\text { - To set up a communication and coordination system } \\
\text { - To set up a brainstorming procedure for decision making }\end{array}$ & $\begin{array}{l}\text { - To set up a system of } \\
\text { monitoring and internal and } \\
\text { external control }\end{array}$ & UB \\
\hline Training & $\begin{array}{l}\text { - Training to implement processes } \\
\text { - Training on decision-making tools }\end{array}$ & $\begin{array}{l}\text { - Training to implement } \\
\text { processes } \\
\text { - Training on decision- } \\
\text { making tools }\end{array}$ & UB \\
\hline Maintenance & & - Preventive materials & TB \\
\hline Quality control & $\begin{array}{l}\text { - Conformity of materials } \\
\text { - Conformity of work and implementation means } \\
\text { - Conformity to standards and specifications }\end{array}$ & $\begin{array}{l}\text { - Conformity of materials } \\
\text { - Conformity of work }\end{array}$ & UB \\
\hline
\end{tabular}

\section{Conclusion}

As shown in the present paper, it is possible to use the MADS-MOSAR method for the risk analysis of construction projects. Although it is tiresome, the approach is facilitated by a systemic vision that facilitates emphasis of the systems, the subsystems and the interactions between them. To make the MADSMOSAR method applicable to the construction area, it is important to first establish a table with all types of the system sources of danger specific to construction. Using the black-box technique to connect the initiating to principal events in all possible ways, we can then identify short or long scenarios leading to undesired events. In the presented study case, the MADS-MOSAR method enabled us to identify many risks of a geotechnical nature. Moreover, it highlighted the importance of organizational, decisional, informational and communication issues that have been identified as sources or components of many risk scenarios, leading to pathologies in the roadway and its environment. While proven to be efficient for road construction project risk analysis, the MADS-MOSAR method remains difficult to apply by non-risk specialists. However, because the use of the method is based on consultation, the coordinated work and sharing of knowledge of multidisciplinary groups of actors involved in the studied project, together with the systemic vision offered by the method, are key factors in addressing most of the risk-related issues, including nontechnical ones such as those pertaining to interoperability.

\section{References}

[1] D. Breysse, Maîtrise des risques en genie civil. Volume 1: Multiples dimensions des risques en genie civil. Editions Hermes Science Publications, 2009.

[2] D. Breysse, La maitrise des risques, du projet aux ouvrages existants : Quels enjeux ? Quels outils ?, in INVACO2 : Séminaire International, Innovation et Valorisation en Génie-Civil et Matériaux de Construction, 23-25 Novembre 2011, Rabat, Maroc.

[3] R. J. Chapman, The controlling influences on effective risk identification and assessment for construction design management. Int. J. of Project Management 19(3) : 147-160, 2001.

[4] A. Dassens, R. Launay, Etude systémique de l'analyse de risques - Présentation d'une approche globale. Technique de l'ingénieur, 22 p, 2008.

[5] B. Flyvbjerg, M. S. Holm, S. Buhl, Underestimating costs in public works projects, Error or lie?, Journal of the American Planning Association 68(3) : 279-295, 2002.

[6] L. Gardes, Méthodologie d'analyse des dysfonctionnements des systèmes pour une meilleure maîtrise des risques industriels dans les PME: Application au secteur de traitement de surface. Thèse de doctorat, Institut des sciences appliquées de Lyon et Ecole Nationale Supérieure des mines de Saint Etienne, France, 2001.

[7] D. Gourc, Vers un modèle général du risque pour le pilotage et la conduite des activités de biens et de services. Habilitation à Diriger des Recherches, Institut national Polytechnique de Toulouse, France, 2006.

[8] O. Grandamas, Méthode MADS-MOSAR - Pour en favoriser la mise en œuvre. Technique de l'ingénieur, 16 p, 2010.

[9] S. Grimaladi, C. Rafgele, A tool selection and support methodology for project risk management, in 22nd IPMA word congress, 9- 
11 November 2008, Roma, Italy, 2008.

[10] A. Klemetti, Risk management in construction project networks. Ph.D thesis, Helsinki University of technology, Finland, 2006.

[11] M. Lesbats, J. Dos Santos, P. Périlhoné, Groupe "Méthodologie d'analyse des dysfonctionnements dans les systems (MADS)". Présentation de la science du danger. Urgences Médicales, 16(2) : 53-62, 1997.

[12] O. Malcurat, Modélisation d'un environnement logiciel d'assistance au travail collaboratif dans le secteur de l'architecture et du BTP. Thèse de doctorat, Institut National Polytechnique de Toulouse, France, 2001.

[13] F. Munoz, A. Vignes, L. Perrin, O. Dufaud, A. Laurent, D. Thomas, J. Bouillard J, Comment assurer la sécurité d'un laboratoire utilisant des nanoparticules?, in 11ème Congrès de la Société Française de Génie des Procédés, 9-11 October 2007, Saint-Etienne, France.

[14] T.H. Nguyen, Une méthode pour évaluer l'impact des risques et aider au choix stratégique de traitement des risques : Application au pilotage de projet, in 8ème Congrès International de Genie Industriel, 10-12 June 2009, Bagnères de Bigorre, France.

[15] P. Perilhon, Analyse des risques, éléments méthodiques. Phoebus, la revue de la sûreté de fonctionnement, l'analyse de risques 12: $31-49,2000$.

[16] P. Perilhon, MOSAR - Présentation de la méthode. Technique de l'ingénieur, 16 p, 2003.

[17] P. Perilhon, MOSAR - Cas industriel. Technique de l'ingénieur, 24 p, 2004.

[18] P. Perilhon, La gestion des risques. Méthode MADS MOSAR II - Manuel de mise en œuvre. Les éditions Demos, 2007.

[19] L. Perrin, F. Munoz-Giraldo, O. Dufaud, A. Laurent, A, Normative barriers improvement through the MADS/MOSAR methodology. Safety Science 50(7) : 1502-1512, 2012.

[20] A. Sienou, A, Proposition d'un cadre méthodologique pour le management intégré des risques et des processus d'entreprise. Thèse de doctorat, Institut National Polytechnique de Toulouse, France, 2009.

[21] P.-X. Thivel, Y. Bultel, F. Delpech, Risk analysis of a biomass combustion process using MOSAR and FMEA methods. Journal of Hazardous Materials 151(1) : 221-231, 2008.

[22] J. Tixier, G. Dusserre, O. Salvi, D. Gaston, Rewiew of 62 risk analysis methodologies of industrial plants. Journal of Loss Prevention in the Process Industries 15(4) : 291-303, 2002.

[23] T. Verdel, Méthodologies d'évaluation globale des risques - Applications potentielles au génie civil, in Colloque International Risques et Génie Civil, 8-9 November 2000, Paris, France. 